\title{
МАРКЕРЫ СОСУДИСТЫХ ОСЛОЖНЕНИЙ САХАРНОГО ДИАБЕТА 2 ТИПА: ВЫБОР ОПТИМАЛЬНОЙ ТЕРАПИИ
}

\author{
Хайдарова Ф.А., Латипова М.А.
}

Республиканский специализированный научно-практический медицинский центр эндокринологии имени академика Е.Х. Туракулова, Ташкент, узбекистан

АКтУАЛЬНОСть: сахарный диабет одно из самых распространенных неинфекционных заболеваний в мире. По данным экспертов ВОЗ заболеваемость СД носит характер эпидемии, охватывающей все экономически развитые страны. Общее число больных СД в мире в настоящее время составляет 230 млн. человек, а к 2025 году число их достигнет 380 миллионов человек. При этом доля больных с СД 2 типа составляет 8590\%. Однако значительная часть случаев СД 2типа протекает без очевидных клинических симптомов и остается нераспознанным в течение длительного времени. Заболеваемость СД 2 значительно возрастает среди лиц 35-40 лет и старше, и достигает максимальных значений в возрастных категориях $\geq 60$ лет. С момента дебюта заболевания до установки диагноза и начала лечения у большого числа таких пациентов проходит около 10 лет. В результате, СД 2 типа выявляется уже на стадии тяжелых, необратимых поздних осложнений, которые могли бы быть успешно предотвращены при своевременном начале лечения.

ЦЕЛЬ: определить маркеры сосудистых осложнений СД 2 типа и выбрать оптимальную терапию.

ОБЪЕКТ ИССЛЕДОВАНИЯ: НаблюДать больНЫХ СД 2 тиПа с макро И микро СосУДистымИ ослоЖНениями, применить новых инновационных сахароснижающих препаратов.

РЕзУЛЬТАТЫ: системные сосудистые осложнения признаны самыми опасными последствиями заболевания. Поэтому снижение риска развития микро и макро сосудистых осложнений СД 2 типа является важной терапевтической целью. Наиболее изученными белками острой фазы воспаления в настоящее время являются С-реактивный белок (СРБ), интерлейкин-6 (ИЛ-6), фактор некроза опухоли альфа (ФНО-а) и GDF15- один из маркеров эндотелиальной дисфункции, ухудшения эхокардиографической систолической функции левого желудочка и заболевания периферических артерий. GDF15 защищает сердце от повреждения и является биомаркером, отражающим воспаление и окислительный стресс. Новые инновационные сахароснижающие препараты, к которым преимущественно относятся агонисты рецепторов глюкагоноподобного пептида 1 (арГПП-1), ингибиторы дипептидилпептидазы 4 (иДПП-4) и ингибиторы натрий-глюкозного котранспортера 2 (иНГЛТ-2) способны управлять не только гликемией, но и другими факторами сердечно-сосудистого риска. Которые являются самыми распространенными факторами риска развития макрососудистых осложнений при СД 2 типа признаны ожирение, дислипидемия, артериальная гипертензия. Среди инновационных сахароснижающих препаратов занимают агонисты рецепторов ГПП-1. Помимо влияния на уровень $\mathrm{HbA1c}$, и веса положительно влияет на кардиоваскулярные действия. арГПП-1 снижают содержание общего ХС, ЛПНП, триглицеридов и увеличивают уровень ЛПВП, влияние на эндотелиальную дисфункцию и окислительный стресс улучшение микроциркуляции, увеличение синтеза NO, подавление окисления ЛПНП; антигипертензивное действие - нормализация АД в нескольких исследованиях арГПП-1, не зависящая от динамики массы тела и гликемии; антиатеросклеротический эффект -уменьшение размеров атеросклеротических бляшек, торможение пролиферации гладкомышечных клеток сосудов. Ингибиторы НГЛТ-2 рекомендованы как приоритетные при наличии у пациентов сердечной недостаточности, а арГПП-1 - при преобладании признаков атеросклеротического сердечно-сосудистого процесса. Длительный прием указанных препаратов сопровождается уменьшением массы тела на 2-3 кг вследствие утилизации жиров в качестве источника энергии и потери 200-300 ккал/сут с мочой. Ингибиторы НГЛТ-2, как правило, повышают уровень ЛПНП; уменьшает уровня маркеров воспаления и окислительного стресса, способствующих прогрессированию атеросклероза это важно учитывать, поскольку пациенты с СД находятся в зоне повышенного риска сердечно-сосудистых заболеваний. Ингибиторы дипептидилпептидазы-4 (ДПП-4) - новая группа сахароснижающих препаратов, механизм действия которых основан на инкретиновом эффекте. Инкретинами являются глюкозозависимый инсулинотропный полипептид (ГИП) и глюкагоноподобный пептид-1 (ГПП-1).

Секреция фермента дипептидилпептидазы-4 тесно связанно с повышением концентрации глюкозы в эндотелиальных клетках микрососудистого русло. Таким образам ингибирование фермента глиптинами повышает не только антигипергликемический но и ангиопротекторный эффект. 